\title{
THE SUBJECT MATTER OF PHYSICS AND METAPHYSICS IN JACQUES LEGRAND'S COMPENDIUM UTRIUSQUE PHILOSOPHIE
}

\author{
Daniel A. Di Liscia* \\ Munich Center for Mathematical Philosophy (Calculatores Project) \\ Ludwig-Maximilians-Universität München
}

\section{INTRODUCTION}

As it is well known, Aristotle classifies the sciences into speculative, practical and productive (Met. VI.1, 1026a 18-19). The criteria for this classification, its background and its possible consequences are for him not obvious declarative statements we may acritically assume without further discussion. Moreover, at several places of his work, especially in his Metaphysics, Physics and Posterior Analytics, he addresses many difficulties by distinguishing their methods, their aims, and especially concerning the speculative disciplines, their respective fields of research objects. Do the combination of matter and motion provide an adequate criterion for a useful differentiation between the speculative sciences, physics, metaphysics and mathematics? And, if it seems to be clear that mathematics is about another set of objects, how are the first two of them to be distinguished one from the other if both should deal with the entire reality? The question is even more pressing insofar as one has to confirm that Aristotle does not consider as an absolutely obvious question what the subject matter of metaphysics is. On the contrary, the chain of thought in his Metaphysics makes rather evident the efforts of a searching philosopher trying to determine the highest field of speculation. If on the one side, the generalization of physics jeopardizes the distinction between physics and metaphysics, the determination of the latter as «science of God» lef the way open to theology, a way of course, that many thinkers of the Middle Ages were willing, if not compelled, to follow. The new trends in logic and the significance that particular scientific fields were reaching during the late 14 th century and the beginning of the 15 th century were two ponderous factors which induced a more intensive discussion about the general set of problems concerning the classification of sciences. A case study which could be considered particularly convenient to appreciate this special situation in the late medieval history of ideas is available in the Compendium utriusque philosophie composed by Jacques Legrand, a complex and substantial handbook on natural philosophy which deserves more attention than has been payed to it until now. ${ }^{1}$ Thus, the general purpose of this contribution is to offer an account of

\footnotetext{
* I would like to thank the Deutsche Forschungsgemeinschaft for its generous support which made possible this and further publications of my project «Die Geometrisierung der Metaphysik im Spätmittelalter: Jacobus de Neapoli und die Tradition De perfectione specierum». In addition, I am very grateful for both of the referees' remarks which have greatly helped to improve the quality of this contribution.

1 As for other words, I shall accept in this paper the usual late medieval spelling «philosophie» instead of «philosophiae». See also below «IV Editorial remarks».
} 
these questions in this work. To this aim, I am firstly going to provide some general information about the text, the author and the current state of research. Secondly, I shall discuss the corresponding part of the work on the classification of the speculative sciences. Third and finally, I will produce an edition of the discussed parts of the work, which are the first three chapters of the first part. $^{2}$

\section{JACQUES LEGRAND AND HIS COMPENDIUM UTRIUSQUE PHILOSOPHIE}

The Compendium utriusque philosophie by Jacques Legrand was analyzed for the first time by Lynn Thorndike, firstly in a specific paper, which he later included unchanged in his monumental History of Magic and Experimental Science. ${ }^{3}$ Without knowing its author and reading the text solely from the Paris manuscript (here $\mathbf{P}$ ), Thorndike delivered a general account of the work in which he described according to his line of investigation the principal contents of the text as well as some special features of it. Under these he included several references to the reception of the new methods and concepts regarding the quantification of qualities and motions produced originally some decades before by the Oxford calculators and later incorporated - not without many differences and even criticism - in the Parisian natural philosophy from the middle of the 14 th century. ${ }^{4}$ Especially, Thorndike emphasized the role played by the notion of «perfection» (perfectio) describing the varied spectrum within which it is presented in the Compendium and linking it to Oresme's doctrine of configurations and to the pseudo-Oresmian doctrine of the latitude of forms. Even though he was focusing on magic, alchemy and "experimental science", Thorndike did not exaggerate by underlying the importance of this kind of content in the Compendium, which, after all, dedicated an impressive amount of pages to expand the discussion about the different types of perfection, its augmentations and diminutions, its comparison to other types of perfection and its role in the ordered universe of the Middle Ages; an universe which should be capable of comprehending the totality of beings, from God to stones - and still beyond them, including the privationes or «negations of being» - in a meaningful hierarchical system. ${ }^{5}$ This topic was excellently taken up by John Murdoch, who carried out a more general and at same time more precise discussion of the notion of perfection in the context of the mathematising methods usual in the philosophy and theology from the 14th century. ${ }^{6}$ Also Edward Grant showed interest in this text, which he discussed according to $\mathbf{P}$ as anonymous and from which he

2 I am preparing a critical edition of the complete work using both manuscripts.

3 Thorndike, L., «An Anonymous Treatise in Six Books on Metaphysics and Natural Philosophy», The Philosophical Review 40, (1931), pp. 317-40 and A History of Magic and Experimental Science, New York, Columbia Univ. Press, 1923-1958, 8 vols., here vol. III (1934), pp. 569-84.

4 Sylla, E. D., «The Oxford Calculators», in N. Kretzmann, A. Kenny, and J. Pinborg (eds.), The Cambridge History of Later Medieval Philosophy, Cambridge, Cambridge University Press, 1982, pp. 545-63.

5 For a still useful background, without knowledge of this text, but with a chapter on medieval thought, see Lovejoy, A., The Great Chain of Being. A Study of the History of an Idea, Cambridge, Massachusetts, Harvard University Press, 1970. Chapter III: «The Chain of Being and Some Internal Conflicts in Medieval Thought», pp. 67-98.

6 Murdoch, J. E.: «Mathesis in philosophiam scholasticam introducta. The Rise and Development of Application of Mathematics in Fourteenth Century Philosophy and Theology», in Arts libéraux et philosophie au moyen âge. Actes du IVe Congrès international de Philosophie médiévale (Université de Montréal, 27 août2 sept. 1967), Montréal-Paris, 1969, pp. 215-54. 
quoted many passages on the classification of sciences, some of which are part of the text edited in this paper.

Whereas neither Thorndike nor Murdoch nor Grant knew the author of the Compendium, as they only discussed the content of the text according to the anonymous Parisian manuscript, Evencio Beltrán had been able already in 1974 to find a second copy of this text in the Biblioteca Berio from Genova (manuscript C.F. 53, here G). ${ }^{8}$ This copy is provided with some additional details which made possible for Beltrán an indirect but still convincing attribution to an author's name: Jacobus Magnus or, as he can be called, Jacques Legrand. The knowledge of the author and the existence of a second copy put the state of the question around the Compendium on a new basis. Certainly, the name of an author, whoever she/he was, is of course something in itself valuable. But above all, this revealed that this special text had been composed by a very prolific and significant author.

While the origins of Jacques Legrand (approx.' 1360-1415/18) are still in the dark, it seems to be certain that his center of activity was Paris around the turn of the century. ${ }^{9}$ Here, he was occupied not only with his academic career but also with politics and public affairs. ${ }^{10}$ Furthermore, he was a member of the order of the Hermits of Saint Augustine, so that his interest in the topic of the "perfectio specierum», which seems to constitute a focal point of attention in the theological and philosophical education within the order, is surely not a coincidence. $^{11}$

Legrand left an impressive series of works, above all on theology, moral philosophy, and different educative and religious topics, not only in Latin but also in French. Not all his works aroused, however, the same interest. Some of them, to mention only some of those which are closer to philosophy, are extant in two manuscripts (as for instance our Compendium and the collection of Aristotelis, Senece, Boecii dicta communiora) or even in only one (as his Tractatus de arte memorandi and his Lectura super quattuor libros Sententiarum). On the contrary, others are conserved in several copies. Especially notable are his Livre des bonnes meurs and his Sophilogium, a work which with more than a hundred and ten manuscripts belongs to the most widespread texts of the time. ${ }^{12}$

The first doctrinal contribution on this text after the identification of the second copy in the De Berio library was to my knowledge the valuable paper by Dietrich Lohrmann, who

7 Grant, E., A History of Natural Philosophy from the Ancient World to the Nineteenth Century, Cambridge e.a., Cambridge University Press, 2007, pp. 165-9.

8 Beltrán, E., «Jacques Legrand O.E.S.A. Sa vie et son oeuvre», Augustiniana, 24 (1974), pp. 132-160; pp. 387-414. For the Compendium, pp. 395-6.

9 Beltrán, E., o.c. «Jacques Legrand O.E.S.A. ...», p. 136.

10 Beltrán, o.c. «Jacques Legrand O.E.S.A. ...», pp. 147-157. Legrand was directly connected to Charles VI, the famous French King called «le Bien-Aimé» and «le Fou». For further details on Legrand's life see Beltrán, o.c., «Jacques Legrand O.E.S.A. ...», pp. 132-160 and also Beltrán, E., «Jacques Legrand prédicateur», Analecta Augustiniana, 30 (1967), pp. 148-209.

11 That this topic was especially cherished within the Augustinians is a thesis which has been advanced by Corvino I can now only agree with and hope to reinforce in further contributions. See Corvino, F., «Il De perfectione specierum di Ugolino d'Orvieto», Acme. Annali della Facoltà di Filosofia e Lettere dell'Università Statale di Milano, 7 (1954), pp. 76-77.

12 Cf. Beltrán, o.c. «Jacques Legrand O.E.S.A. ...», pp. 387-414. For a short online presentation based on Beltrán's papers see https://www.arlima.net/il/jacques_le_grand.html Archives de littérature du moyen âge / Rédaction: C. Boucher; Compléments: L. Brun, D. Burghgraeve and M. Schmitz. Last update 19.09.2017. This entry contains a very useful bibliography, which, however, should be supplemented with the contributions by Thorndike, Murdoch, Grant and Lohrmann here mentioned. 
settled Legrand's investigations around the problem of the motus perpetuus in the context of the late medieval history of mechanics and physics. In addition, Lohrmann edited the general introductory prologue to the whole work and the relevant passages of the third book about the motus perpetuus. ${ }^{13}$

As already reported by Thorndike, the Compendium is made up of six parts covering the complete field of natural philosophy, from the more general topics on epistemology and methodology at the beginning to the more strictly empirical ones, as the form of the Earth and mineralogy at the end. ${ }^{14}$ The text was intended, at least this is what its author declares at the very beginning of the foreword, to facilitate the study of the Aristotelian corpus. ${ }^{15}$ According to Beltrán, there are many concrete circumstances which led Legrand to compose this work: While the statutes of the order stipulated that for activity at the Studium of Paris the participants ought to exhibit a solid education in grammar and logic, the chapter from Siena added in 1338 a year of teaching in logic and philosophy. Thus, «Jacques Legrand a dû s'y soumettre puisqu'il a écrit un ouvrage intitule Compendium utriusque philosophie, qu'il declare avoir composé pour les étudiants». ${ }^{16}$ It is clear that, to this goal, Legrand tried to comprehend and summarize those doctrinal contents of the Physics, De caelo et mundo, De anima, and De generatione et corruptione, which, in his opinion, were more relevant. Yet, it is also true that his reorganization of the material, the omissions of some issues, and above all his supplements and additions of other scientific questions not covered by Aristotle, give his text the more original character of an independent work, in which it is not only to be reported what Aristotle could have thought himself but also how the Aristotelian corpus has to be studied, that means interpreted and supplemented. After all, Legrand makes clear at the very beginning of the preface that the texts of Aristotle exhibit too much loquaciousness and words difficulties and furthermore that he will discuss the opinions (sententias) of Aristotle himself and of other philosophers as well. So, Legrand decided himself consciously for an approach which left him enough room for his own reflections and criticism of current doctrines. This is of course a good reason for paying more attention to this text. ${ }^{17}$

\section{THE CONTENT OF THE COMPENDIUM I.1-3}

The first chapter deals with the subject matter of metaphysics, which is, even for Aristotle himself, by no means an obvious question. After all, he warns at several places about the

13 Lohrmann, D., «Motus continuus und motus perpetuus in Technik und Naturphilosophie des späten Mittelalters», in: A. Speer, D. Wirmer (eds.), Das Sein der Dauer, [Miscellanea Mediaevalia 34], Berlin-New York, de Gruyter, 2008, pp. 224-243, especially pp. 237-243. As Lohrmann (p. 237) fairly recalls, there is a previous remark in Thorndike (o.c., p. 578) linking Legrand's ideas to the device Cornelis Drebbel presented much later to James I.

14 Thorndike, o.c., pp. 70-71 and pp. 761-66.

15 Lohrmann, o.c., p. 238.

16 Beltrán, o.c., «Jacques Legrand O.E.S.A. ...», p. 140. I have corrected the typo «inutilé» into «intitulé». By the way, the copy $\mathbf{G}$ found by Beltrán is datable for the year 1402. See below «IV. Editorial Remarks».

17 The Compendium seems to exhibit a greater originality in philosophic-theological matters. «Our work is more than a mere abbreviation», affirms Thorndike (o.c., p. 570) who concedes its author the attempt of going over Albert the Great by interlarding «various recent theories of a different sort» (Ibid.). Yet, at the same time, Thorndike (o.c. p. 572) observes that Legrand's mineralogy is heavily dependent on Albert the Great. See also Grabman, M., Mittelalterliches Geistesleben. Abhandlungen zur Geschichte der Scholastik und Mystik II, München, R. Oldenbourg, 1936, p. 404. 
danger of overlapping with the other two theoretical disciplines and gives this science we used to calling «metaphysics» different names, even the characterization of «the science we are looking for» (Met. IV.1, 1003a 21-5). For medieval thinkers of almost all persuasions, Aristotle's answer to this question is insofar especially significant, as he, in the development of his investigation, refers to this science as the supreme science addressing the supreme being, God (Met. I.1, 983a 5-11 and Met. VI.1, 1026a 17-18, where the three speculative sciences are «mathematics, physics and theology»). A collaboration or, depending on the viewpoint, a conflict of interest between metaphysics and theology, is at the core of this question at least at a latent state. By discussing the issue, Legrand firstly sets down three previous distinctions for avoiding equivocation in the meaning of the terms. According to the first distinction, «subject» (subiectum) is used in the sense of the subject of inherence, as Aristotle had done in Metaphysics (VIII.1, 1042a 2 - 1042b 1-7) by distinguishing between matter and subject. In a second way, we can take «subject» in a pure logical sense, as the subject which in a sentence receives predication. Still in a third case, we can speak of the «subject of attribution» (subiectum attributionis). This third meaning, Legrand states, is determining for his following discussion about what the subject of a scientific discipline, such as physics or metaphysics, indeed is. «Subject of attribution» is a central epistemological notion, as Legrand points out referring to several Aristotelian passages and offering a clear definition, in which by the way it is clear, that this notion supposes the previous notions, especially the logical one, but that it requires more than they do:

«In a third way and corresponding to our purpose 'subject' is to be taken as 'subject of attribution'. And then, 'subject' is called the most general term considered in a science which does not transcend the limits of this science. And all <things $>$ which are principally considered in this science have order or attribution to this term» (lin. 8-11)

As we can see, the «subject of attribution» of a science is the central concept in this science to which all other concepts should be reducible. A traditional example for it, however here not yet mentioned, is the notion of «motus» for physics. Legrand does not quote any sources for this idea of a «subject of attribution», but certainly not because he wishes to be considered its creator but rather because it is a quite widespread notion, which belongs to the standard discussion apparatus in the philosophy of science during the 14th and 15th centuries. ${ }^{18}$ Besides, the concept of «subjectum» is in general important - Legrand adds since a science receives from it five decisive features: 1) «unity», 2) «dignity», 3) «distinction», 4) «order», and 5) «utility». All these aspects depend from the different points of view on the research object of each particular science, as he explains referring in each case to the correspondent loci of the Aristotelian corpus. After these preliminary remarks, Legrand deals with the question itself about the subiectum of metaphysics. ${ }^{19}$ Here, he reports four main opinions. According to the first one, the subject of metaphysics are the causes. This opinion seems to choose a too narrow subject, for, as Legrand affirms referring to Avicenna, metaphy-

18 This is the same conceptual apparatus and exactly the same terminology used for discussing the subject of the scientia de latitudinibus formarum. See Di Liscia, D.A., «The 'Latitudines breves' and Late Medieval University Teaching», SCIAMVS 17 (2016), pp. 55-120, and Di Liscia, D.A., "The 'latitude of forms' as a new middle science» (forthcoming) and the references here included.

19 For a thorough research work on this topic see, Zimmermann, A., Ontologie oder Metaphysik?: die Diskussion über den Gegenstand der Metaphysik im 13. und 14. Jahrhundert: Texte und Untersuchungen, Leuven, Peeters, 1998. 
sics deals not only with causes but also with the essence of the effects. Furthermore, reminds Legrand mentioning Aristotle, the metaphysician certainly focuses on the causes and principles, but only insofar as they are beings (entia).

The second opinion establishes that God is the subject of metaphysics, something that, of course, could be supported by quoting several Aristotelian passages. The formulation however, which Legrand chooses for the support of this thesis contains a not uninteresting component. He draws attention to the fact that this opinion is sometimes supported by the conviction that metaphysics is «maxime divina», because it deals with God. At this point, Legrand makes it clear that he is absolutely against this view. He sustains that metaphysics is a «human science» and that one cannot investigate God with a human understanding. Hence, God cannot be assigned to metaphysics as its subject. There would be still a way around to affirm this thesis nevertheless by saying that the characterization of metaphysics as «divine» does not pretend a demonstrative analysis of God's essence and properties, but only an investigation of God «as far as the human understanding without the help of the faith is possible» (lin. 46-49). This attenuated version of the second opinion is also to be refused. The argument used by Legrand against it is remarkable, even if it is overly concisely formulated. This version of the thesis wishes only to affirm God as the subject of metaphysics, although we are not able to reach a complete knowledge of it. Legrand's argument against it runs: «Since human investígation regarding God is modest - or insufficient (modica) -, it does not seem < to be correct $>$ that the subject of metaphysics should be taken from a science or investigation which one has on God through metaphysics» (lin. 49-51). With other words: by suggesting God as subject of metaphysics, this opinion supposes a research object that is completely insecure because, as itself admits, its knowledge is insufficient.

The third opinion - held by Simonides as mentioned in Aristotle's Metaphysics -, sustains that metaphysics, for mankind, is not possible at all; such a science is reserved to God. Legrand does not detain himself to discuss this opinion in detail, which he simply refuses by mentioning a counterexample: Plato, as Augustine testified, was a great metaphysician. The fourth opinion, finally, is the one which he considers closer to the truth (because he, anyway, does not say «vera» but «verior») and this is Aristotle's opinion, "who sustained that the being as being is the subject of metaphysics, since to metaphysics or first philosophy belongs to deal with the passions or properties of the being as being» (lin. 60-63). Thus, the «ens inquantum ens», as Aristotle says in the famous passage of the fourth book of Metaphysics, should be the subject (the subjectum attributionis) of this discipline. Legrand reinforces this opinion by quoting Averroes and by emphasizing additionally the understanding of metaphysics as «first philosophy» according to Aristotle's remark in Metaphysics VI.1, where he points out a serious problem of possible objects overlapping: if all objects were movable, not metaphysics but physics should be called the first philosophy. However, there is a certain substance which is immovable, so metaphysics remains the first philosophy. From this remark Legrand draws the consequence that the consideration from the point of view of motion cannot be put at first place but is a derived consideration. On the contrary, Legrand assumes a point of view which is linked to logic and theory of knowledge. According to this, one should take into consideration which concept of a thing is produced in the first place. Here, in line with the Liber de causis, he remarks that in fact the first concept we have of the created things is the concept of their being («primus conceptus habetur de esse rei» (lin. 75-79). That fits at all events the notion of metaphysics as «first philosophy». In addition, Legrand discusses two possible objections or «doubts» (dubia, dubitationes) to this opinion which are internally 
connected to each other: It seems that we do not have any experience of a thing as being firstly apprehended «secundum esse». And, if that were the case, one could still ask why one should not prefer physics instead of metaphysics for teaching and learning. The answer to the first doubt is that we in fact have such a first comprehension of the thing through the substance underlying and supporting the properties (or of the subject receiving predicates), but the speed of the (naturally working) understanding is so high that we do not realize that we indeed do conceive, for instance, «Socrates» before we then conceive «Socrates is white». To the second doubt Legrand answers that, actually, there are no troubles if we prefer in general («quo ad magnam partem») metaphysics to physics in teaching and learning, since many physical demonstrations are to be reduced to metaphysical demonstrations for the sake of clarity. Because, of course, metaphysics deals with elevated speculations, as for instance, the separate substances, one may prefer to postpone this kind of objects. This having been established, Legrand joins still a consideration which is not immediately obvious and which connects both doubts and both answers. Metaphysics takes into account not only the being of the thing, the pure «esse», but it investigates further on what this thing is, the «quid sit». Thus, even if «Socrates» is prior than «Socrates is white», we do not conceive previously the «quid sit» than «Socrates is white». The reason for that is that if, for instance, the «quid sit» of Socrates is being «a substance with a rational soul» (lin. 99-100), we do not arrive to this knowledge until a longer process. For, the ascertainment of such an elevate property of the thing requires a longer way of investigation than a statement about the motion or the color of Socrates. Hence, the final conclusion of Legrand, trying to conciliate both approaches is that regarding to the principles, which are more rational and more evident, one should prefer metaphysics to physics; regarding the conclusions, however, one should take the opposite way around.

In the second chapter, Legrand addresses the subject of natural philosophy or physics. ${ }^{20}$ He presents three main positions. The first one affirms that «nature» is to be assumed as the subject of natural philosophy because the denomination of the discipline at all is taken from it. Averroes adds to this that natural things (naturalia) are those things for whose definition we use the concept of nature. One could also construct a similar explanation indirectly, recurring to the notion of motion, like that: Natural philosophy deals with those things which are connected to motion. But nature is defined by Aristotle as a «principle of motion» (so, for instance, in Phys. II.1). Thus, one could take «nature as a principle of motion» as the subject of natural philosophy. Legrand dismisses this opinion on the grounds of a homogenization between the notions of «nature» and «essence», which is in my opinion less satisfactory. So, he states that there are in fact many things which have an essence, which can be called their nature, about which, nevertheless, natural philosophy is not. This argument, however, is useful because it can be expanded to an extent to which the before mentioned notion of «not transcending the limits» (metas non trascendens) is involved. As we have seen at the beginning, this is a crucial notion for defining the central concept of «subject of attribution». But what is exactly meant by that? We have a good example in this argument, which resumed runs

20 Whereas the term «physics» could be understood as narrowly limited to the contents of Aristotle's Physics, the expression «natural philosophy» has the advantage of including the topics corresponding to all other books which as a matter of fact are also discussed in the Compendium. Legrand seems slightly to prefer the latter, but often enough he passes to «physics» in the midst of an argumentation. For the problem of the subject-matter of natural philosophy in the 13th century and its reception at the university of Cologne, see Donati, S., «Una questione controversa per i commentatori di Aristotele: il problema del soggetto della fisica», in A. Zimmermann (ed.), Die Kölner Universität im Mittelalter, Berlin-New York, de Gruyter, 1989, pp. 11127. 
like that: All things have an essence. Essence can be understood as nature. If then natural philosophy deals with nature as its subject, it deals with all existing objects. But - that is to be set as a premise - a science has to cut out its own subject from the totality of being. Natural philosophy would be in this case incapable of fulfilling this condition. The reason for that is that the concept of nature transcends the limits of the field it should precisely demarcate. Hence, «nature» cannot be the subject of natural philosophy in the sense of «subject of attribution» as explained before.

This argument can be challenged, of course, by enlarging the set of objects belonging to natural philosophy: if we take all objects (and then we do not accept the «cutting out premise») we will not have the problem of nature as a transcending notion. What would then mean that physics is about all things («de omnibus rebus»)? Legrand offers two possibilities: In the first case it is meant that the used terms are supposing for all things, as for instance when by discussing some physical theories or phenomena we say that the things we are talking about are «generable» or «in-generable», «finite» of «infinite». For, all things are, remaining on this last example, either finite or infinite. In the second case, physics deals with all things including some connection to physical nature, as for instance by dealing with God not as God but as the motor of a process, or when dealing with a triangle not as such but a kind of physical quantity which could be moved locally (lin. 129-131).

After these pre-explanations, Legrand turns back to answer in more detail the previous objections (motus) which were raised (movebantur) at the beginning of the chapter. To the objection regarding the determination of the subject by the denomination of the discipline, that means, since the discipline is called «philosophia naturalis», hence its subject is «nature», he replays that this argument is just a verbal argument, not a real one. And, of course, since words are «ad placitum» the argument fails. That explains furthermore that there are, in fact, many sciences the names of which are not taken from their subjects. To the second objection, which was based on the notion of nature as a principle of motion, Legrand replays that under the premise that the subject of a science should be adjusted (coequari) to its limits, the term «motion» is more adequate than «nature» because it is narrower. In general, for the denomination of a subject it is better to take the more precise term than the more comprehensive. Finally, pretending to draw on the concept of nature as a principle of motion is not a valid procedure, for in this case we should also accept that God is the principle of motion and then we would have immediately God as the subject of physics, which is insofar not acceptable because the subject would not be adequate to the limits of this science.

According to the second opinion, which some philosophers adduce recalling for support an Aristotelian remark in De caelo et mundo, the subject of natural philosophy is «this whole movable body» (lin. 144). Here, Aristotle says that physics deals mostly (plurima) with bodies. This opinion would be correct if - explains Legrand - the subject was to be taken for those things which physics deals with (he means here the contents of the Physics). To reinforce this approach, one could remember that Aristotle states in Phys. VI that as «every body is movable, also every movable is a body». ${ }^{21}$ Besides, physics considers its objects as connected to motion. Hence, it seems that «body» is a good candidate for the subject of natural philosophy. However, Legrand dismisses this opinion on the reason that «many not-bodies are considered

21 A sentence that, at least in this formulation, is not easy to find in Aristotle's text but, as many of the quotations here, occurs in the Auctoritates Aristotelis and in Thomas Aquinas' lectures on Physics as well. See V. Text, footnote 46 . 
by natural philosophy, such as God insofar he is a motor, and the rational soul» (lin. 151-152). In general, the reasons exposed before are to be refused as being too narrow. For, they show in fact that the bodies are to be studied within physics, what does not mean that they fulfil the conditions to be the subject of this science. That would require that all objects belonging to this science could be covered, but this does not happen if we assume «body» as the subject.

The third opinion, finally, is that of the «moderns», who sustain that «this whole movable being is the adequate subject of natural philosophy» (lin. 157-158). ${ }^{22}$ That is the usual opinion which Legrand wishes to support as well and this, as he somehow confusedly notes, is also Aristotle's opinion. This subject comprehends all things which have an essential link to motion insofar as this narrower term «motus» is now combined with the most general term «ens» in the formula «ens mobile».

The third chapter about the question whether these two sciences, metaphysics and physics are practical or speculative sciences, is more modest in its theoretical substance. ${ }^{23}$ In view of the general purpose of the Compendium comprehending both fields of philosophical speculation might have been reasonable to show, at least at a didactical level, that these fields are not to be confounded with the practical ones.

As usual, Legrand starts by setting some preliminary conceptual distinctions, in this case on «science». In a linguistic abusive way, this notion can be understood as valid for all knowledge or, more specifically, for the knowledge of the conclusions and of the premises in a reasoning. In its proper sense, one should understand by science «the habit acquired by demonstration, since 'to know' is to understand through demonstration» (lin. 172-173) and hence, «science is the habit of conclusions whereas understanding is the habit of the principles» (lin. 174). Legrand tries to confirm this statement by referring to Aristotle, although he might have the opinion of some current philosophers in mind. ${ }^{24}$

Following the well-known distinction between speculative and practical science, Legrand reminds us according to Averroes and Aristotle that a speculative science has the aim to know, whereas the practical one has the goal to act. So, the general question can be smoothly answered by saying that metaphysics and physics are speculative sciences because their aim is to know. In addition, Legrand appends a doubt which is immediately connected with the academic circumstances around these two disciplines. One could ask why it happens that some people who deal with metaphysics or physics connect their study with a practical purpose. The answer to this question is that this fact does not have to decide about the question of the nature of a science, whether it is speculative or practical. All activities around the praxis of people doing physics or metaphysics - that they are good at talking or at teaching, that they make their living by that means, and the like - are only extrinsic aspects which do not influence the ascertainment of those sciences as speculative because they are, even without all these aspects, good. Now, one could still object that precisely this consequence problematises a clear

22 To the moderns most probably belongs John Buridan, as Grant has indicated (o.c., p. 168).

23 For the background, with several references to medieval philosophy, see Ebbersmeyer, S., «Spekulation», in. J. Ritter - K. Gründer (eds.), Historisches Wörterbuch der Philosophie, Basel, Schwabe, 9 (Se-Sp), 1995, col. 1355-1372.

24 So for instance, Albert of Saxony, who in his logical questions writes: «antecedens probabur, nam omnis scientia acquitur per demonstrationem» (Fitzgerald, M. J., Albert of Saxony's Twenty-five Disputed Questions on Logic. A Critical Edition of his Quaestiones circa logicam, Leiden e.a., Brill, 2002, pp. 58-9). For the concept of «habitus» in the context of the discussion on the subject matter of metaphysics see Zimmermann, o.c. pp. 129-30. 
distinction between both speculative and practical disciplines, for the latter also include their work as a purpose. Thus, «the science whose purpose is the work (opus) cannot reach a complete goodness without this work» (lin. 194-195). ${ }^{25}$ To understand that one could take as an example medicine, which, as Averroes says, «starts its consideration there, where the physics stops» (lin. 195-97). This is a practical discipline and, even if one started speculating, it remains a practical one because of its practical goal (which, we may here suppose, is not to know for instance some natural processes or phenomena of the human body, but rather to cure it when it is ill).

\section{EDITORIAL REMARKS}

By editing the first three chapters of Le Grand's Compendium I shall use both known manuscripts, which are in a very readable hand and convey a consistent text, as having the same value.

$\mathbf{G}=$ Genoa, Biblioteca Berio, C.F.53, fols. 2r-235v. This copy is dedicated to Michel de Créney, Bishop from Auxerre and father confessor of the French King Charles VI. On ff. 2r$8 \mathrm{r}$ it includes not only the list of all parts and chapters but also a detailed alphabetical index of concepts. The explicit contains the date 1402, which apparently is only valid for the finishing of the copying work: «Explicit presens opus complete scriptum in vigilia nativitatis beate marie virginis anno domini 1402 deo gratias» (fol. $235 \mathrm{v}){ }^{26}$

$\mathbf{P}=$ Paris, Bibiothèque Nationale, lat. 6752, fols. 4r-236r. This copy has no date but owner's marks bearing the names of Jean Valin and René Valin. ${ }^{27}$

Although $\mathbf{G}$ contains some further information which was decisive for the attribution of the text to Legrand by Beltrán, there is, concerning the part of the text edited here, no special reasons to prefer it. Firstly, because $\mathbf{P}$ contains also a very good text, sometimes even slightly better than $\mathbf{G}$ and, secondly, because $\mathbf{G}$ demonstrate many signs of having being corrected. The copyist had another copy before his eyes, which apparently is not $\mathbf{P}$.

I will reproduce the spelling which was usual in late medieval Latin writing with «e» for «ae» in the genitive and similar cases (that means, I will not normalize the text according to classical Latin). I decided to choose «nil» instead of «nihil», because this form appears in both manuscripts (although «nichil» would be also possible). Furthermore, I unified some words which are different in both manuscripts, as «definitio» (instead of «diffinitio»), meta/metas according to $\mathbf{P}$ (instead of «metha»/《«methas» according to $\mathbf{G}$ ) and «opiniones» in $\mathbf{P}$ against «oppiniones» in $\mathbf{G}$ (where anyway «opinio» appears, as well). I shall also unify «Physica/ Metaphysica» (G contains mostly «Methaphysica») for the Aristotelian books and «physica/metaphysica» (not «phisica/metaphisica») for the scientific disciplines (accordingly «physice» and «metaphysice» etc.).

25 Thus, this science requires an acting subject completing works, which lies outside the scope of pure speculative sciences.

26 This seems to be also the interpretation of Beltrán (o.c., p. 395), when he writes «L'un des manuscrits qui nous transmettent cette oeuvre est daté de 1402».

27 For further information see Seńko, W., Repertorium commentariorum medii aevi in Aristotelem Latinorum quae in bibliothecis publicis Parisiis asservantur. Bibliothèque Nationale, Arsenal, Mazarine, Sorbonne, Ste. Geneviève, Warsaw, Warszawa Akademia Teologii Katolickie, 1982, pp. 114-6. 
A last remark about the sources mentioned in the Compedium. It is not a secret that, as medieval authors often quoted indirectly or mentioned sources by heart, they are neither exact nor accurate. Hence, they represent a challenge for editors which they could only approximately fulfil offering references as a starting point for the contextualization of the edited text. A special challenge in this regard represents the medieval version of Aristotle's Metaphysics, a text which with eleven quotations is the most often referred source in this part of the Compendium. Legrand mentions also some passages from the Physics, De caelo et mundo, De anima, and Posterior Analytics. After Aristotle, the most often quoted author is Averroes mostly referring to his commentary on Metaphysics -, but also Avicenna, Augustine (referring back to Plato) and the anonymous Liber de causis are mentioned.

\section{TEXT. JACOBI MAGNI COMPENDIUM UTRIUSQUE PHILOSOPHIE. PARS I, CAPITULA 1-3}

\section{Primum capitulum de subiecto metaphysice}

Quia scientia quelibet a suo subiecto recipit denominationem ideo de subiectis dicta- G13 ${ }^{r}$ rum scientiarum prius est tractandum. Ne tamen de subiecto equivoce loqui credamus, illam communem notabimus distinctionem qua dicitur quod subiectum tripliciter accipitur. $\langle 1\rangle$ Primo $\langle$ modo〉 pro subiecto inhesionis, et illo modo potest dici subiec-

5 tum omne illud cui aliquid inheret. Hoc enim modo de subiecto loquitur Aristoteles $8^{\circ}$ Metaphysice $^{28}$ ponens differentiam inter materiam et subiectum. $\langle 2\rangle$ Secundo modo capitur subiectum logicaliter pro termino de quo alius terminus predicatur. 〈3〉 Tertio modo et ad propositum capitur subiectum pro subiecto attributionis et tunc subiectum dicitur terminus communissimus in aliqua scientia consideratus non 10 transcendens metas illius scientie ad quem terminum omnia principaliter in tali scientia considerata habent ordinem seu attributionem.

Hoc enim modo loquendo de subiecto investigare oportet quid sit subiectum metaphysice et deinde quid subiectum philosophie naturalis. Hec enim consideratio ideo necessaria est, quia scientia quelibet a suo subiecto quinque recipere perhibetur. Nam pro scientia a suo subiecto recipit $\langle 1\rangle$ unitatem, quia scientia est una que est unius generis, ut habetur primo Posteriorum. ${ }^{29}\langle 2\rangle$ Secundo modo recipit dignitatem, ut patet ex modo arguendi Aristotelis in exordio libri De anima ${ }^{30}$ ubi ostendit librum De anima esse nobiliorem ceteris philosophie libris ratione dignitatis et perfectionis anime, de qua ibi agitur. 〈3〉 Tertio scientia a suo subiecto recipit distinctionem, 20 quia sicut habetur $2^{\circ}$ De anima ${ }^{31}$ secantur scientie quemadmodum et res, quod sic est intelligendum quod scientie distingui habent secundum distinctionem rerum de quibus sunt. $\langle 4\rangle$ Quarto scientia recipit a suo subiecto ordinem ut patet primo Metaphysice $^{32}$ ubi Aristoteles ostendit metaphysicam esse primam scientiarum, quia est

28 Aristoteles, Metaphysica VIII.1, 1042a 2 - 1042b 1-7.

29 Aristoteles, Anal. Post. I.7, 75b 1-3, I.28 87a 38 - 87 b4.

30 Aristoteles, De anima I.1, 402a 1-10.

31 Aristoteles, De anima I.1, 402a 13-24.

32 Aristoteles, Metaphysica I.1, 983a 5-11.

4-5 subiectum ] subiectum om. $\mathbf{P} 21$ est intelligendum ] intelligendum est $\mathbf{P}$ 
de primo ente scilicet de deo. $\langle 5\rangle$ Quinto scientia recipit a suo subiecto utilitatem seu necessitatem, quia scientie | ideo utiles sunt et necessarie et res cognoscere necesse est de quibus sunt. Ideo dicebat Aristoteles primo Metaphysice ${ }^{33}$ quod alique sunt scientie invente propter necessitatem. Hec autem necessitas illis convenit qui feliciter vivere volunt.

$\mathrm{Si}$ igitur subiectum hic communicat que dicta sunt, investigare ergo oportet 30 utriusque philosophie. Et primo videndum est quid sit subiectum metaphysice de quo varias legimus | opiniones.

$\langle 1\rangle$ Quidam enim crediderunt quod iste terminus «causa» esset subiectum metaphysice, quia de causis tractare ad metaphysicum pertinet. Huius opinionis ratio esse potuit, quia scientia quelibet ab eo debet denominari de quo principaliter con35 siderat, quia ergo de causis universalibus sicut de deo et angelis ad metaphysicam spectat determinare. Ideo apparet quod ab illis suam debet sortiri denominationem et consequenter subiectum. Hec tamen opinio falsa est, ut patet per Avicenam in principio sue Metaphysice ${ }^{34}$ dicentem quod subiectum metaphysice non est causa, quia non solum de causis imo etiam de quidditate effectuum ad metaphysicam de40 terminare spectat. Imo dicit Aristoteles $6^{\circ}$ Metaphysice ${ }^{35}$ quod metaphysicus non considerat de principiis et causis rerum nisi inquantum sunt entia.

$\langle 2\rangle$ Alia opinio fuit quorundam credentium quod deus esset subiectum metaphysice, quorum opinio roborari potest ex eo quod metaphysica est maxime divina, quia de deo est ut dicitur primo Metaphysice. ${ }^{36}$ Hec tamen opinio est falsa, quia meta45 physica est humana scientia. Deus autem humano ingenio investigari non potest. Non debet ergo deus pro subiecto metaphysice assignari. Nec valet predicta ratio cum dicitur quod metaphysica divina est, non quia dei essentiam seu proprietatem demonstrat sed quia deum investigat quantum humano ingenio sine fide possibile est. Cum igitur humana investigatio respectu dei modica sit, ideo non videtur quod 50 subiectum metaphysice accipi debeat a scientia seu investigatione que per metaphysicam de deo habetur. Et ita hic terminus «deus» subiectum metaphysice non debet censeri.

〈3〉 Insuper aliorum opinio fuit quod metaphysica homini non erat possibilis sed deus solus eam habebat et consequenter de eius subiecto nil videretur tractandum. 55 Huius opinionis fuit Simonides philosophus, ut narratur primo Metaphysice. ${ }^{37}$ Sed hec opinio frivola est |, quia plures metaphysicos legimus inter quos Platonem pre- G14 ${ }^{r}$ cipuum commemorat Augustinus. ${ }^{38}$ Poterimus ergo dicere Simonidem defecisse aut

33 Aristoteles, Metaphysica I.1, 981b 20-22.

34 Avicenna, Liber de philosophia prima, tract. 1, cap. 1, in Avicenna Latinus. Liber de philosophia prima sive de scientia divina I-IV, ed. S. Van Riet (Louvain-Leiden, Peeters-Brill, 1977) p. 6, lin. 97, p. 8, lin. 32.

35 Aristoteles, Metaphysica VI.1 1025b 1-2, VI.4 1028a 3-4.

36 Aristoteles, Metaphysica I.2, 983a 5-11.

37 Aristoteles, Metaphysica I.2, 983a 1-10.

38 There are certainly several passages in Augustine where Plato's philosophy is praised with emphasis, especially for its alleged independence of and even superiority over the corporeal world - something that doubtlessly must belong to Agustine's notion of metaphysics. See for instance, Confessiones VII.20 or De vera religione, cap. $2-4$.

29 ergo ] om. $\mathbf{P} 44 \mathrm{est}^{2}$ ] ideo G 46 ante pro ] scilicet scr. et del. G 47 non ] om. G, interl. $\mathbf{P} 54$ eam ] om. $\mathbf{P}$, interl. $\mathbf{G}$ 
forsan nomine metaphysice theologiam intellexisse que sine fide nobis impossibile est. Sic autem dicere honorabilius videtur.

〈4〉 Rursus alia opinio fuit Aristotelis quam estimo veriorem, qui posuit quod ens inquantum ens est subiectum metaphysice, quia ad metaphysicam seu ad philosophiam primam pertinet considerare de passionibus seu proprietatibus entis secundum quod ens, ut dicitur $4^{\circ}$ Metaphysice. ${ }^{39}$ Unde Commentator super $\mid$ sexto $\mathbf{P} 6^{r}$ Metaphysice $^{40}$ dicit quod metaphysica considerat res separatas a motu et materia 65 secundum esse et inquantum entia sunt. Ex quo patet quod ens inquantum ens debet dici subiectum metaphysice. Nam primum principium metaphysice ad quod omnia reducuntur est illud quo dicitur $4^{\circ}$ Metaphysice $^{41}$ de quolibet esse vel non esse et de nullo simul. Si ergo istud principium est primum, cum ergo fundetur in ratione essendi, consequenter videtur quod ratio entis metaphysice congruit. Insuper idem potest roborari, quia teste Aristotele metaphysica est scientiarum prima, ut patet $6^{\circ}$ Metaphysice ${ }^{42}$ ubi sic dicit si - inquit - omnis substantia est mobilis physica est philosophia prima. Sed aliqua est immobilis, ergo non physica sed metaphysica debet prima philosophia vocari. Ex isto argumento colligi potest quod consideratio rei secundum motum non est prima consideratio. Imo potius primus conceptus de re possibilis habetur sub ratione essendi, scilicet inquantum res habet esse. Et hoc satis volebat innuere auctor De causis ${ }^{43}$ dicens quod prima rerum creatarum est esse, quod sic potest intelligi quod primus conceptus habetur de esse rei. Si tunc metaphysica est prima philosophia, ut predictum est, consequenter eius subiectum a primo conceptu debet denominari cuiusmodi est ens.

80 Hic tamen dubitatur quia non experiamus omnem rem primo considerari secundum esse. Et si ita experiamur adhuc oritur dubium quare metaphysica in docendo seu addiscendo physice non prefertur. Ad primum dubium dicendum quod licet quandoque non experiamur primum conceptum de re aliqua habitum versari contra rationem essendi, sic est tamen quod primus conceptus habetur de esse rei quia primo concipimus Sortem esse quam Sortem esse album. Verum quod sepius tanta est promptitudo intellectus quod talis prioritas non percipitur. I Itaque nobis primo videtur quod eque primo concepimus Sortem esse album sicut Sortem esse, quod falsum est, quia naturalis ordo permutari non potest et signantur quando agentia sunt naturalia cuiusmodi est intellectus cuius operatio naturalis est et non libera. Ad secundum dubium dici potest quod non esset inconveniens metaphysicam quo ad eius magnam partem tam in docendo quam in addiscendo physice preferri. Quod patet, quia in multis demonstrationibus physicis oportet recurrere ad demonstrationes metaphysicales quia evidentiores et clariores in|veniuntur. Quia tamen in metaphysica $\mathbf{P}^{v}$ tractantur alte speculationes, ut puta de substantiis separatis, ideo metaphysicam tanquam altiorem et difficiliorem postponere placuit. Vel etiam dici potest quod non

39 Aristoteles, Metaphysica IV.1, 1003a 20-23, IV.2, 1005a 1-5.

40 Averroes in: Aristotelis Opera cum Averrois Commentariis, Venetiis, Apud Iunctas 1562-1574 [reprint Frankfurt a/M., Minerva 1962], vol. VIII, Metaphysica, VI, o.c., f. $146^{\prime}$ b.

41 Aristoteles, Metaphysica IV.4, 1006a 28-30.

42 Aristoteles, Metaphysica VI.1, 1026a 29-30.

43 Liber de causis II.20 and IV.37.

60 ante estimo ] ex scr. et del. G $62 \mathrm{seu}]$ et $\mathbf{G} \|$ ante entis ] entium scr. et del. $\mathbf{G} 75$ habet ] habent $\mathbf{P}$ 
solum metaphysica considerat rem esse, imo etiam cum rem esse cognoverint ulterius investigat quid sit, licet ergo prius sit Sortem esse quam Sortem esse album non tamen prius est concipere quid est Sortes quam concipere Sortem esse album, quia si concipimus quid est Sortes tunc concipimus quod Sortes est substantia animata rationalis. Hec autem consideratio multo altior est quam sit de motu vel albedine Sortis. Ex quibus patet quod metaphysica physice potest in docendo rationabiliter preferri quantum ad eius principia, quia communiora et evidentiora sunt; quantum vero ad conclusiones contrario videtur agendum.

\section{Capitulum secundum: de subiecto philosophie naturalis}

Ulterius inquirendum est de subiecto philosophie naturalis de quo varie leguntur opiniones.

〈1〉 Quidam enim dixerunt quod natura debebat subiectum philosophie naturalis nuncupari eo quod a natura philosophia naturalis nomen accepit. Unde sicut dicit Commentator $6^{\circ}$ Metaphysice ${ }^{44}$, naturalia sunt illa in quorum definitione ponatur natura. Insuper idem probatur, quia philosophia naturalis considerat res coniunctas motui, ut primus allegatum est. Quia ergo natura est principium motus videtur ergo quod a natura tanquam a principio motus subiectum philosophie naturalis derivari debeat. Hec tamen opinio vera non apparet eo quod multa sunt entia habentia naturam de quibus philosophia naturalis non tractat, nam essentia cuiuslibet rei potest eius natura vocari. Quia ergo de qualibet re ad physicum tractare non spectat, consequenter nec de qualibet natura. Ex quo patet quod iste terminus «natura» transcendit metas | philosophie naturalis. Non debet ergo subiectum phisice G15r nuncupari. Hic dubitatur, quia philosophia naturalis est de omnibus rebus, igitur hic terminus «natura» non transcendit metas eius. Ad hoc respondetur communiter quod physicam esse de omnibus rebus intelligi potest dupliciter: 〈a〉 primo 〈modo〉

120 sic quod philosophia naturalis utitur terminis supponentibus pro omnibus rebus; et sic conceditur quod physica est de omnibus rebus nam isti termini «generabile» et «ingenerabile» qui sunt termini ad physicam spectantes supponunt pro omnibus rebus, quia $\mid$ omnis res est ingenerabilis vel generabilis aut saltem non generabilis. Et P7r hoc dico propter aptitudinem connotatam in termino privativo. Potest etiam dari exemplum de istis terminis «finitum» et «infinitum», quorum suppositio ad res omnes se extendere videtur. Omnis enim res finita vel infinita est. $\langle$ b Secundo modo physicam esse de omnibus rebus sic intelligi potest quod ad physicam de qualibet re determinare spectat seu de qualibet natura inquantum est talis res seu talis natura. Sic enim intelligendo physica non est de omnibus rebus, quia non est de deo inquantum deus est sed inquantum motor est; nec est de triangulo inquantum triangulus est sed inquantum est quedam quantitas localiter mobilis.

Sed restat dicendum ad ea que in contrarium movebantur. Dicebatur enim quod physica a natura nomen accepit, quia communiter philosophia naturalis appellatur,

44 Averroes in: Metaphysica, VI, o.c., f. $146^{r}$ b. Auctoritates Aristotelis, ed. by J. Hamesse, Les Auctoritates Aristotelis. Un florilège médiéval, Louvain-Paris, Publications Universitaires-Béatrice-Nauwelaerts, 1974 [«Philosophes Médiévaux, XVII»], p. 128 (156).

101 potest ] interl. $\mathbf{P}$ 
dicendum quod hic argumentum vocale est et non reale. Multe enim sunt scientie quarum nomina a subiectis non accipiuntur, quia usus vel placitum instituentis nomina sepius imposuit. Ad aliud motum dicitur quod, licet natura sit principium motus, tamen potius ratio subiecti attenditur penes motum quam penes naturam eo quod motus strictior terminus est quam natura. Quia ergo subiectum limitibus sue scientie debet coequari. Ideo melius est denominationem subiecti accipi a termino magis preciso quam a communiori. Nec valet cum dicitur natura est principium motus, nam pariter dici posset quod deus est principium motus et consequenter deum subiectum physice haberi. Que ratio ideo non valet, quia ratio subiecti non consistit in hoc quod est terminus limitibus scientie adequatus ut profertur.

$\langle 2\rangle$ Ceterum alia fuit opinio quorundam dicentium quod hoc totum | corpus mobile erat subiectum philosophie naturalis, quorum opinio per hoc potest roborari quia ut dicitur tertio Celi et $\mathrm{Mundi}^{45}$ plurima consideratio philosophie naturalis est de corporibus. Si ergo subiectum debeat accipi penes ea de quibus tractat physica sequitur opinio vera. Item ad idem arguitur, quia ut dicitur $6^{\circ}$ Physicorum $^{46}$ omne corpus est mobile et omne mobile est corpus. Ex quo ergo physica considerat res 150 coniuctas motui. Ergo videtur quod corpus possit esse eius subiectum. Hec tamen opinio ideo falsa apparet, quia multa non corpora sunt de consideratione philosophie naturalis, sicut $\mid$ deus inquantum motor est, et anima rationalis. Nec valent rationes dicte opinionis, quia solum concludunt quod corpus est de consideratione physice, quod conceditur, sed non sufficit ut habeat rationem subiecti. Imo ulterius requiri-

155 tur quod se extendat ad omnia que principaliter in physica considerantur, quod non facit corpus, ut predictum est.

〈3〉 Insuper tertia est modernorum opinio ponentium quod hoc totum ens mobile est subiectum adequatum philosophie naturalis. ${ }^{47}$ Que opinio videtur vera eo quod tale subiectum se extendet ad omnia que habent ordinem essentialem ad motum, quod patet, quia iste terminus «motus» coniungitur huic termino communissimo, scilicet isti termino «ens», ut patet cum dicitur ens mobile. Hanc opinionem satis videtur innuere Aristoteles $2^{\circ}$ Physicorum $^{48}$ cum dicit quod entia non mota amplius non sunt physice considerationis quasi diceret quod entia mota sunt physice considerationis. De istis tamen dubiis et similibus sub forma questionum atque conclusionum quandoque expediet secundum ordinem textus presentis si temporis facultatem dominus largiatur extensius tractare.

45 Aristoteles, De caelo et mundo III.1, 298b 2-4, Auctoritates Aristotelis, o.c., p. 165 (74).

46 Cf. Auctoritates Aristotelis, o.c., p. 154 (172) and Thomas Aquinas, In octo libros Physicorum Expositio, IV, lect. 23, n. 626, ed. by M. Maggiòlo, Taurini-Romae, Marietti 1965, p. 309.

47 Cf. John Buridan, Quaestiones super octo libros Physicorum Aristotelis (secundum ultimam lecturam), Libri I-II, M. Streijger - P. J.J.M. Bakker (eds.), Leiden-Boston, Brill, 2015, q. I.3 (pp. 22-9.): utrum ens mobile sit subiectum proprium totalis scientiae naturalis vel quid aliud.

48 Aristoteles, Physica II, 198a 27-28.

135 ante usus ] ad scr. et del. G 141 deum ] om. P 147 ante corporibus ] corporalibus scr. et del. G || tractat] in marg. G, est $\mathbf{P} 152$ et ] sicut etiam $\mathbf{G} 157$ modernorum opinio ] opinio modernorum $\mathbf{P} 160$ huic ] om. $\mathbf{G}$ 


\section{Tertium capitulum: de qualitate utriusque philosophie, an sint practice vel speculative}

Nunc tractare oportet an metaphysica et physica sint scientie practice vel speculative. Pro cuius declaratione advertendum quod scientia capitur multipliciter. $\langle 1\rangle$ Primo modo pro omni cognitione. Sed iste modus largus et abusivus est. $\langle 2\rangle$ Secundo modo capitur pro cognitione tam conclusionum quam principiorum, et sic accipiendo etiam abusus est. $\langle 3\rangle$ Tertio modo proprie | scientia est habitus per demonstratio- G16 ${ }^{r}$ nem acquisitus, nam scire est per demonstrationem intelligere, ut dicitur $2^{\circ}$ Posteriorum. ${ }^{49}$ Unde scientia est habitus conclusionum; intellectus vero est principiorum, ut ibidem dicitur.

Ulterius distinguendum est de scientiis, quia alique sunt practice, alique speculative. Scientia speculativa dicitur illa cuius finis est scire, practica cuius finis est operari, ut dicit Averroys $2^{\circ}$ Metaphysice. ${ }^{50}$ Unde $3^{\circ}$ De anima ${ }^{51}$ dicit quod scientia practica et speculativa penes finem distinguuntur. Si ergo queritur an metaphysica atque physica sint scientie practice vel speculative responderi potest quod speculative prout determinat Aristoteles $6^{\circ}$ Metaphysice $^{52}$, quia earum finis est scire. Cum ergo a fine res debeat determinari, sequitur propositionum. Hic tamen dubitatur, quia physicam atque metaphysicam plures student finem practicum sibi constituen|tes. Ad quod dicendum quod scientia non debet dici practica vel specula- $\mathbf{P} 8^{r}$ tiva propter finem quem quis sibi constituit sed propter finem ad quem scientia talis destinata est, quia ergo metaphysica atque physica sunt scientie speculative que de se bone sunt et intellectum perficiunt et sunt de genere bonorum honorabilium absque hoc quod praxis aliqua ex eis eliciatur. Ideo si contingat aliquam practicam per eas haberi, ut puta, bene legere, bonum loqui, seu victum docendo lucrari, hec tamen omnia extrinseca sunt, quia sine his dicte scientie gratia sui bone sunt. Nec sic potest de scientiis practicis allegari quia scientia que practica est opus tanquam finem sibi constituit sine quo complementum suum non habet, quia sicut dicitur $2^{\circ}$ Metaphysice $^{53}$ qui tollit finem tollit omne bonum. Unde Commentator ibidem ait quod finis

49 Aristoteles, An. Post. II.19, 99b 15-19. The definition of science as «a habit acquired by demonstration» is extremely widespread in medieval philosophy of science. This reference is actually in both manuscripts to «primo» Posteriorum, where I was not able to find a corresponding passage. I think, however, that it is a wrong reference to the beginning of II.19, where the notion of «héxis» occurs, which was frequently translated in Latin as «habitus». It possible that Legrand is following here Buridan's Metaphysics commentary, which in the second question to the first book (Utrum metaphysica sit sapientia) introduces the same definition, refering also to the first book of the An. Post.:«... quia omnis habitus intellectualis acquisitus per demonstrationem vel demonstrationes est scientia, ut habetur primo Posteriorum». Johannes Buridanus, In Metaphysicen Aristotelis questiones argutissimae...., Parisiis, 1518 [reprint Minerva, Frankurt a. M. 1964], fol. $3^{v} \mathrm{~b}-4^{r} \mathrm{a}$.

50 Averroes in: Aristoteles, Omnia quae, o.c., Metaphysica, II, com. 3, f. $29^{\mathrm{v}} \mathrm{a}$.

51 Averroes, Commentarium magnum in Aristotelis de anima libros, ed. F. S. Crawford, Cambridge, The Medieval Academy of America, 1953, p. 517, lin. 10-12.

52 Aristoteles, Metaphysica VI.1, 1026a 5-25.

53 Aristoteles, Metaphysica II.2, 994a 12-13.

168 Nunc ] Illud $\mathbf{P} 1732^{\circ}$ ] primo GP $177-178$ practica...dicit ] om. P 178 ut dicit ] in marg. P 179 ante distinguuntur ] distinguuntur scr. et del. G 185 quis ] om. $\mathbf{P} 186$ metaphysica atque physica ] physica atque metaphysica $\mathbf{P}$ 
et bonum sunt idem. ${ }^{54}$ Scientia ergo cuius finis est opus suam perfectam bonitatem sine opere habere non potest. Huius exemplum capere possumus de medicina que teste Commentatore libro De sensu et sensato ${ }^{55}$ suam incipit considerationem ubi physicus dimittit, quia si in medicina speculatio habeatur hec a physica originatur. Medicina ergo practica est ex eo quod de se ad opus destinata est. Staret tamen aliquem in medicina speculari et secundum eam nihil operari nihilominus cum medicina propter hoc minus non debet minus practica reputari, quia non obstat finis quem quis sibi libere constituit, ut de speculativa prius dicebatur.

Daniel A. Di Liscia d.diliscia@1rz.uni-muenchen.de

Fecha de recepción: 23/07/2017

Fecha de aceptación: 11/11/2017

54 Averroes, Metaphysica, o.c., com. 8, f. $33^{r}$ a.

55 Cf. Aristoteles, De sensu et sensato I, 436a 19 - b 1, Auctoritates Aristotelis, o.c., p. 195 (2).

200 hoc ] in marg. $\mathbf{G}$ 